\title{
One Prison, One Death, One Mass-Coverup
}

Dawnya Ferdinandsen

\section{Inmate kills herself at ORW}

A twenty-year-old inmate died Friday after she hung herself at the Ohio Reformatory for Women.

Carol Bell, 20, from Greene County, was found hanging from a bed sheet in the cell at 9 P.M. by a corrections officer doing a routine count of prisoners. Bell was alone in the cell at the time.

Bell was serving a 15-50 year sentence on a conviction for aggravated robbery, attempted murder, and kidnapping stemming from an incident in the Dayton area in 1996. She and two accomplices allegedly stabbed a cab driver and took his money.

Bell was 16 at the time.

In March of 1999 she had an additional four years added onto her sentence for attempted escape from the ORW.

She would not have been eligible for parole until 2010.

Attempts to revive Bell were unsuccessful. She was pronounced dead at the scene.

The Ohio State Highway Patrol, which handles incidents on state grounds, was called to the scene to investigate. ${ }^{1}$

\footnotetext{
Carol Ann Bell was sixteen when she arrived at the Ohio Reformatory for Women. She came in very young and afraid, and knew no one in a population of over 1,800 women. At her age and faced with a sentence of sixteen to fifty years, she felt like she was surely going to die here and inevitably she did just that.

Carol Ann had suicidal problems when she arrived here in 1996. In March of 1997, she attempted to hang herself while in lock-up and was placed on watch for a mere day or so before being told she would be all right. In August, 1998, Carol Ann attempted to escape, managing to get over the first perimeter fence before being caught by prison officers. Upon seeing her attempt to escape, a captain took a 357 magnum from a perimeter officer and threatened to shoot her. Carol Ann informed the captain repeatedly that
}

1 Source of article unkown; submitted by author. 
she did not care and that she had nothing to live for. She was then placed immediately in a lock-up area (ARN-4) on suicide watch for over two weeks with no psychiatric evaluations, rushed through institutional hearings and returned to lock-up for another sixty days. She then told officers that she heard voices telling her to kill herself, and was placed back in the Residential Treatment Unit (RTU) from October to December. During this time she was heavily medicated, raced through Union County and given an additional four years for an attempted escape.

The day before she was placed back in the lockup area she slit her wrist; this was brushed off and she was placed back in lock-up with a slit wrist. A captain continuously informed Carol Ann, at eighteen years of age, that he would personally see to it that she did three to five years in her cell for her escape attempt. This taunting caused her to go back on suicide watch, where several male officers allegedly asked her to expose herself to them or they would ensure that she did years in the hole.

Carol Ann was then released into general population in September, 1999, and sent directly to a maximum security cottage, housing the most notorious women in the state of Ohio. She was nineteen years old when sent there, after thirteen months of solitary confinement and no adjustment program back into population. Carol Ann was scared of these women, since prior to her escape attempt she was housed with only young offenders in a segregated housing unit. While in the maximum housing unit, some women stole things from her, threatened and bullied her, and used her for her $\$ 10$ a month state pay.

Her unit continually informed her that she would be getting her blue shirt (close status) to no avail. This was just one more act of cruelty, since while her institutional record scored to decrease her security the institution would not. Two weeks before her death she was informed by a prison official that she would have to wait for another nine months. If I could only explain what state of mind that put her in, her whole outlook on her time here, then you could begin to understand why she should have been placed in a better housing unit, one with less violent offenders, along with better programming opportunities. This is all Carol Ann wanted and the institution knew it. The fact remains that she earned it, her points called for a decrease. She was trying to get through cosmetology school and had completed numerous groups as a way to better herself.

Needless to say, Carol Ann snapped. She said repeatedly that she could not do another year with the maximum security women. Two weeks later, 
Journal of Prisoners on Prisons, Volume 11, 2001

she hanged herself in her single-woman cell. During those last two weeks of her life she had repeatedly tried to find help through our residential treatment unit program and through the outpatient psychiatrist. Carol Ann burned her left forearm several times with a lit cigarette from her wrist to her elbow. The burns were as deep as the tip of your finger. When she went for help she was informed by our psychiatric staff that that was "normal" behaviour for her and that she should return to her cottage. Carol Ann had never burnt herself before.

At 3:30 P.M. on the day of her death, Carol Ann informed an officer that she needed a psychiatrist because she could not handle her feelings. The officer told her, "You'll be okay. Go to your room and sleep it off." After the 4:00 P.M. count, Carol Ann was asked if she wanted to go to dinner. She said, "no." She was never checked again by staff until her lifeless body was found at 8:55 P.M. by another officer. Many prisoners had told the officers that Carol Ann was very upset and that they should check on her. One prisoner informed them that Carol Ann was banging on her locked door for help, but they brushed her off for the last time. Carol Ann covered the window of her door at 6:30 P.M.; the officers never checked on her from 5:30 P.M. on. Carol Ann died around 7:40 P.M. and was not found until 8:55 P.M., and only then because it was an institutional count time.

This means that she slit her wrists, tore a bedsheet up, strung it up to her window latch, climbed up to the window sill while her wrists bled, made a noose and tightened it around her neck, and leaped to end her tragically young life. Had continuous rounds been made like the maximum security post orders state for officers to do, her window being covered would have been discovered and she would never had the time to slit her wrists and hang herself.

Now the institution wants to point the blame at her relationship, saying that she hanged herself because she and her girlfriend broke up earlier that day. Staff has held meetings with other prisoners (juveniles, mentally ill, and maximum prisoners) telling them that the suicide is a result of Carol Ann's relationship. The bottom line to them is that suicide is no one's fault. However, institutional negligence in meeting responsibilities is in question here. The meetings have consisted of slanderous remarks, along with ludicrous comments by staff about her family, friends and her intimate partner, suggesting that had we known her better we would have seen this coming, and pointing the finger at her only means of support. They are trying to take 
the focus off themselves, the only ones who had the keys and degrees to save her.

Carol Ann was a child pushed through the cracks and forgotten. Please do not let her be forgotten now. I know that people in society will say that she was just a convict, but she too is one of God's children and only God has the right to judge her. The system that vowed to rehabilitate her is the very system that in the end destroyed her life. The true story of Carol Ann Bell needs to be told to ensure that a tragedy like this never happens again. If you need any further information and feel compelled to be Carol Ann's voice, please contact her mother, Jane Ann Zertuche at 308 Trunk Drive, Dayton, Ohio 45431, or call (937) 254-6891.

\section{POSTSCRIPT:}

Since the death of Carol Ann Bell, her other friends and I have been harassed; our mail stopped, opened and read; and outgoing mail has never left the institution. The contents of these envelopes were Carol Ann's story, and the institution does not want to release it to the public. The amount of cover-up here makes it evident that this was not an unforeseen suicide. The entire case needs to be investigated thoroughly.

Dawnya Ferdinandsen is currently incarcerated in the Ohio Reformatory for Women. Her prisoner number is 27006 and she can be reached at the ORW, 1479 Collins Avenue, Marysville, Ohio 43040, U.S.A. 